\title{
HES1, two programs: promoting the quiescence and proliferation of adult neural stem cells
}

\author{
Lachlan Harris and François Guillemot \\ The Francis Crick Institute, London NW1 1AT, United Kingdom
}

\begin{abstract}
Adult neural stem cells are mostly quiescent and only rarely enter the cell cycle to self-renew and generate neuronal or glial progenies. The Notch signaling pathway is essential for both the quiescent and proliferative states of neural stem cells. However, these are mutually exclusive cellular states; thus, how Notch promotes both of these programs within adult neural stem cells has remained unclear. In this issue of Genes \& Development, Sueda and colleagues (pp. 511-523) use an extensive repertoire of mouse genetic tools and techniques to demonstrate that it is the levels and dynamic expression of the Notch transcriptional effector Hairy and Enhancer of Split 1 that enables this dual role.
\end{abstract}

During brain development, neural stem cells (NSCs) proliferate continuously while generating neuronal progenitors and glia and eventually differentiate. In adults, a small number of NSCs populate specialized niches within the hippocampal dentate gyrus and the lateral ventricles. While a fraction of these adult NSCs proliferates to generate neuronal progenitors or glial cells, they are primarily quiescent. This quiescence preserves the NSC pool into old age, ensuring that neurons can be generated when needed (Urbán and Guillemot 2014).

The Notch pathway is essential for both the proliferative and quiescent states of NSCs (Imayoshi et al. 2010). Proliferation and quiescence are alternative cellular states and involve mutually exclusive cellular programs; thus, how Notch promotes both of these programs within adult NSCs is a puzzling and unaddressed question. In this issue of Genes \& Development, Sueda et al. (2019) determine that it is the levels and dynamic expression of the Notch effector protein Hairy and Enhancer of Split 1 (HES1) that enables this dual role.

In previous work, the investigators had determined the mechanism through which Notch signaling promotes the proliferation of embryonic NSCs and had shown how inhi-

[Keywords: active neural stem cell; Ascl1; Hes1; notch signaling; oscillatory expression; quiescent neural stem cell] Corresponding author: francois.guillemot@crick.ac.uk Article is online at http://www.genesdev.org/cgi/doi/10.1101/gad.325761. 119. bition of this pathway drives neuronal differentiation (Imayoshi et al. 2013). Specifically, they had determined that Notch signaling induces proliferation via activating the expression of the transcriptional repressor HES1, whose protein levels oscillate due to autorepression (Hirata et al. 2002). The oscillation of the HES1 protein then induces the out of phase oscillation of its target gene, Achaete-scute homolog 1 (Ascl1), which in turn activates the transcription of positive regulators of cell cycle progression. Conversely, inhibition of the Notch pathway down-regulates HES1 below a critical level, resulting in sustained, rather than oscillatory, ASCL1 expression and the induction of neuronal genes (Imayoshi et al. 2013). Thus, in embryonic NSCs, the activation or inhibition of the Notch signaling pathway determines whether a NSC proliferates or differentiates, respectively (Fig. 1).

In adult NSCs, the mutually exclusive programs of both quiescence and proliferation are promoted by Notch signaling (Imayoshi et al. 2010). Thus, in this present study, the investigators addressed the perplexing question of how Notch signaling promotes both states. Using an extensive repertoire of mouse genetic tools, they examined the relationship between HES1 and ASCL1 in quiescent and proliferating adult NSCs. Using HES1 and ASCL1 fusion reporter mouse lines, they compared the in vivo expression of these proteins in NSCs of the adult hippocampus and lateral ventricles. They observed HES1 oscillations in both the proliferating and quiescent states. However, HES1 oscillated at markedly higher levels in the quiescent state (in which ASCL1 was undetectable) than in the proliferating state (in which ASCL1 was expressed and oscillated in the opposite phase). These observations suggested a model in which high oscillatory HES1 in quiescent NSCs leads to the strong suppression of ASCL1 and to quiescence, whereas low oscillatory HES1 stimulates proliferation by enabling the oscillatory expression of ASCL1.

(C) 2019 Harris and Guillemot This article is distributed exclusively by Cold Spring Harbor Laboratory Press for the first six months after the full-issue publication date (see http://genesdev.cshlp.org/site/misc/ terms.xhtml). After six months, it is available under a Creative Commons License (Attribution-NonCommercial 4.0 International), as described at http://creativecommons.org/licenses/by-nc/4.0/. 


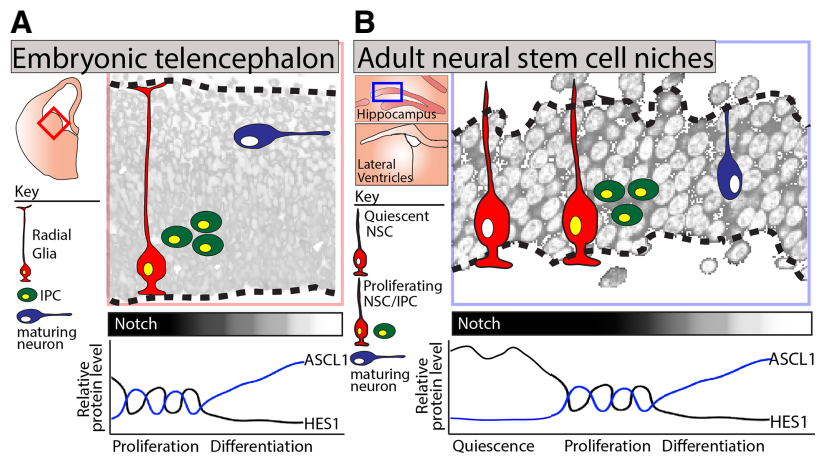

Figure 1. HES1 and ASCL1 expression dynamics in embryonic and adult NSCs. (A) NSC proliferation in the ventral telencephalon is orchestrated by the oscillatory expression patterns of the Notch effector HES1 and its target, ASCL1, with subsequent Notch inhibition and stabilization of ASCL1 driving neuronal differentiation. (B) Adult NSCs are primarily quiescent. Sueda et al. (2019) demonstrate that Notch promotes both the quiescent and proliferative states of adult NSCs through regulating the levels and expression dynamics of HES1. (IPC) Intermediate progenitor cell.

To test this model, the investigators deleted Hes1 within adult NSCs on a mouse genetic background lacking Hes3, Hes5, and Hey1. Loss of Hes1 in this context led to the up-regulation of ASCL1, a doubling in the number of active NSCs, and the premature depletion of the NSC pool. This indicated the requirement for HES1 in maintaining quiescence. Next, the investigators examined the respective contributions to quiescence of increased HES1 levels and of HES1 oscillations by generating a knock-in mouse strain in which Hes 1 was stably expressed from the Rosa26 locus. This experiment helped distinguish between two scenarios: one in which the quiescent state of NSCs is conferred by both the levels and oscillation of the HES1 protein and another in which only the high levels of HES1 influence the quiescent state. In these Rosa26:: Hes 1 mice, quiescent NSCs failed to activate. Thus, these experiments indicated that the increased level of HES1 protein, irrespective of oscillations, is sufficient to promote the quiescent state of NSCs.

Finally, to examine whether ASCL1 oscillations were sufficient to induce the proliferation of adult NSCs, as for NSCs in the embryo, they induced ASCL1 oscillations in quiescent NSCs using a lentivirus with a Hes5 promoter. Compared with controls, quiescent NSCs infected with the Ascl1 virus proliferated more frequently and generated more neurons, demonstrating that ASCL1 oscillations are sufficient to promote the exit from quiescence and the proliferation of adult NSCs. Together, these findings outline how the dynamic expression of HES1 in adult NSCs can confer a quiescent or proliferative state via its regulation of ASCL1 (Fig. 1).

These findings raise new and important questions. For instance, what are the signals that drive the reduction in HES1 as NSCs exit quiescence? One mechanism might be the relative availability of BMPs within the microenvironment. BMP signaling is key to maintaining the quies- cent state of adult NSCs and acts by inducing the expression of the ID family (Mira et al. 2010). ID proteins dimerize with HES1 to prevent its autorepression, increasing HES1 levels, and also sequester the dimerization partner and promote the degradation of ASCL1 protein (Viñals et al. 2004; Bai et al. 2007). Thus, a reduced concentration of BMP ligands within the niche might lead to the downregulation of HES1, the up-regulation of ASCL1, and exit from quiescence.

It is also not clear whether the down-regulation of HES1 is always necessary for adult NSCs to exit quiescence. Indeed, in mice infected with the Hes5::Ascl1 virus, the induction of ASCL1 oscillations in quiescent NSCs with high HES1 induced proliferation. This suggests that NSCs with high HES1 could exit quiescence by amplifying the low levels of ASCL1 through HES1-independent mechanisms; e.g., by inhibition of the ubiquitin-ligase HUWE1 (Urbán et al. 2016). The proliferation of these high HES1 NSCs could help explain why some NSCs have the capacity to return to quiescence upon degradation of ASCL1 instead of immediately re-entering the cell cycle and then being lost through differentiation (Urbán et al. 2016).

In conclusion, this study and the investigators' previous works have established a framework to understand how the dynamic expression patterns of HES1, ASCL1, and other basic helix-loop-helix proteins can influence the quiescence, proliferation, and differentiation of NSCs. Importantly, these mechanisms appear conserved; for example, another study in this issue of Genes \& Development by Lahmann et al. (2019) demonstrated that the oscillations of HES1 controls the balance between proliferation and differentiation of activated muscle stem cells. In the future, it will be important to determine how the dynamic expression patterns of HES1 and related proteins are influenced by niche signals and, in turn, by physiological regulators of stem cell activity such as injury and aging.

\section{References}

Bai G, Sheng N, Xie Z, Bian W, Yokota Y, Benezra R, Kageyama R, Guillemot F, Jing N. 2007. Id sustains Hes1 expression to inhibit precocious neurogenesis by releasing negative autoregulation of Hes1. Dev Cell 13: 283-297. doi:10.1016/j.devcel .2007 .05 .014

Hirata H, Yoshiura S, Ohtsuka T, Bessho Y, Harada T, Yoshikawa K, Kageyama R. 2002. Oscillatory expression of the bHLH factor Hes1 regulated by a negative feedback loop. Science 298: 840-843. doi:10.1126/science.1074560

Imayoshi I, Sakamoto M, Yamaguchi M, Mori K, Kageyama R. 2010. Essential roles of Notch signaling in maintenance of neural stem cells in developing and adult brains. I Neurosci 30: 3489-3498. doi:10.1523/JNEUROSCI.4987-09.2010

Imayoshi I, Isomura A, Harima Y, Kawaguchi K, Kori H, Miyachi H, Fujiwara T, Ishidate F, Kageyama R. 2013. Oscillatory control of factors determining multipotency and fate in mouse neural progenitors. Science 342: 1203-1208. doi:10.1126/sci ence. 1242366

Lahmann I, Bröhl D, Zyrianova T, Isomura A, Czajkowski MT, Kapoor V, Griger J, Ruffault P-L, Mademtzoglou D, Zammit PS, et al. 2019. Oscillations of MyoD and Hes1 proteins 
regulate the maintenance of activated muscle stem cells. Genes Dev (this issue). doi:10.1101/gad.322818.118

Mira H, Andreu Z, Suh H, Lie DC, Jessberger S, Consiglio A, San Emeterio J, Hortigüela R, Marqués-Torrejón MÁ, Nakashima K. 2010. Signaling through BMPR-IA regulates quiescence and long-term activity of neural stem cells in the adult hippocampus. Cell Stem Cell 7: 78-89. doi:10.1016/j.stem.2010.04.016

Sueda R, Imayoshi I, Harima Y, Kageyama R. 2019. High Hes1 expression and resultant Ascll suppression regulate quiescent vs. active neural stem cells in the adult mouse brain. Genes Dev (this issue). doi:10.1101/gad.323196.118
Urbán N, Guillemot F. 2014. Neurogenesis in the embryonic and adult brain: same regulators, different roles. Front Cell Neurosci 8: 396 . doi:10.3389/fncel.2014.00396

Urbán N, van den Berg DL, Forget A, Andersen J, Demmers JA, Hunt C, Ayrault O, Guillemot F. 2016. Return to quiescence of mouse neural stem cells by degradation of a proactivation protein. Science 353: 292-295. doi:10.1126/science .aaf4802

Viñals F, Reiriz J, Ambrosio S, Bartrons R, Rosa JL, Ventura F. 2004. BMP-2 decreases Mash1 stability by increasing Id 1 expression. EMBO / 23: 3527-3537. doi:10.1038/sj.emboj. 7600360 


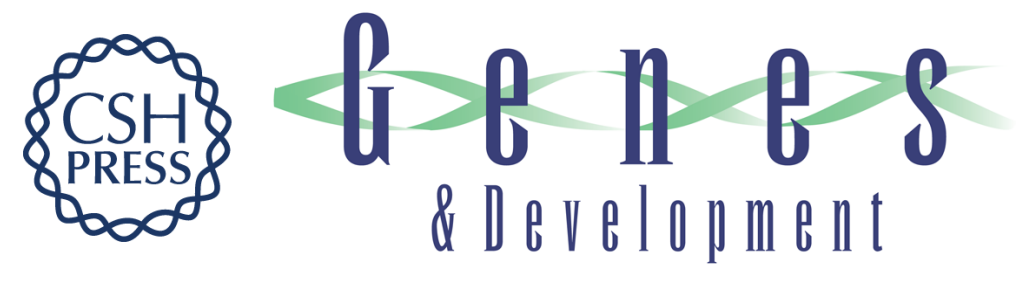

\section{HES1, two programs: promoting the quiescence and proliferation of adult neural stem cells}

Lachlan Harris and François Guillemot

Genes Dev. 2019, 33:

Access the most recent version at doi:10.1101/gad.325761.119

Related Content High Hes1 expression and resultant Ascl1 suppression regulate quiescent vs. active neural stem cells in the adult mouse brain

Risa Sueda, Itaru Imayoshi, Yukiko Harima, et al.

Genes Dev. May , 2019 33: 511-523 Oscillations of MyoD and Hes1 proteins regulate the maintenance of activated muscle stem cells

Ines Lahmann, Dominique Bröhl, Tatiana Zyrianova, et al.

Genes Dev. May, 2019 33: 524-535

References This article cites 10 articles, 7 of which can be accessed free at:

http://genesdev.cshlp.org/content/33/9-10/479.full.html\#ref-list-1

Articles cited in:

http://genesdev.cshlp.org/content/33/9-10/479.full.html\#related-urls

Creative This article is distributed exclusively by Cold Spring Harbor Laboratory Press for the first Commons License six months after the full-issue publication date (see

http://genesdev.cshlp.org/site/misc/terms.xhtml). After six months, it is available under a Creative Commons License (Attribution-NonCommercial 4.0 International), as described at http://creativecommons.org/licenses/by-nc/4.0/.

Email Alerting
Service

Receive free email alerts when new articles cite this article - sign up in the box at the top right corner of the article or click here.

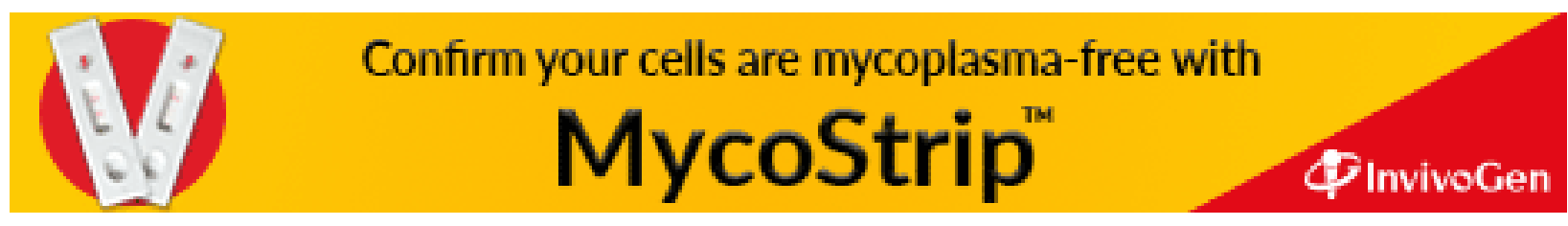

